\title{
Effects of the Presence of Pyrite and Carbonate Minerals on the Kinetics of the Uranium Release from a Natural Rock
}

\author{
Noubactep C. ${ }^{(\mathrm{a})} *$, Sonnefeld J. ${ }^{(\mathrm{b})}$, Merten D. ${ }^{(\mathrm{c})}$, Heinrichs T. ${ }^{(\mathrm{a})}$, Sauter M. ${ }^{(\mathrm{a})}$ \\ (a) Centre of Geosciences - Applied Geology; Universität Göttingen; Goldschmidtstrasse 3, D - 37077 Göttingen \\ (b) Institute of Physical Chemistry, Friedrich-Schiller Universität Jena; Lessingstrasse 10; D - 07743 Jena

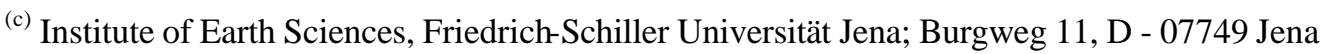 \\ (*) corresponding author: cnoubac@gwdg.de; Tel. +49 55139 3191, FAX: +49 551399379
}

\begin{abstract}
The influence of calcite, dolomite, pyrite and vaterite on the kinetics of uranium (U) release from a natural rock under relevant i.e. field conditions has been investigated. The time dependence of the $\mathrm{U}$ release has been studied in two different experimental procedures (open and closed systems) at laboratory temperature $\left(21 \pm 2{ }^{\circ} \mathrm{C}\right)$. Performing batch experiments in tap water, the U release efficiency of a natural U-bearing rock was characterised in the presence of varying amounts of three different carbonate bearing minerals for experimental durations of up to 782 days. Another experiment was conducted for a period of 14 days in the presence of a pyrite mineral. The results demonstrate that the presence of carbonate minerals does not have any significant influence on $U$ release in closed systems where the $U$ concentration at saturation was ca. $54 \mathrm{mg} / \mathrm{L}$. In contrast, in open systems, the U concentration was ca. $8 \mathrm{mg} / \mathrm{L}$ at saturation and the effects of all additives both on kinetics and saturation concentration of $U$ were apparent.
\end{abstract}

Key Words: contaminant, carbonate minerals, remediation, uranium rock, kinetics. 


\section{Introduction}

Metal release from mining and mine wastes is an environmental problem of worldwide concern. For example, rain water infiltrating into tailing materials, may cause the oxidation of sulphide minerals. The subsequent dissolution of these minerals causes acid mine drainage (AMD) which in turn induces metal release from sulphides $\left(\mathrm{FeS}_{2}, \mathrm{CuFeS}_{2}, \mathrm{PbS},(\mathrm{Zn}, \mathrm{Fe}) \mathrm{S} \ldots\right)$ and other minerals (e.g. $\left.\mathrm{UO}_{2}\right) \cdot{ }^{1-3}$ The assessment of environmental impact of waste rocks, due to acidity release is an ongoing field of intensive research. ${ }^{1,4,5}$ Contaminant release from waste rocks at sites with neutral $\mathrm{pH}$ values has received relative little attention and selected rocks have been proposed for the long term in-situ immobilization of certain contaminants at neutral pH values. ${ }^{6-14}$

The technology of removing contaminants such as $\mathrm{Pb}, \mathrm{U}, \mathrm{Cd}, \mathrm{Cu}, \mathrm{Ni}$ from groundwater downgradient of a plume by reactive barriers with for instance hydroxyapatite or phosphate rocks as reactive material has been discussed. ${ }^{8,13}$ This application implicitly assumes that the used rocks (e.g. phosphate rock or the in situ generated minerals) will be reactive over a long period of time until their full capacity is consumed by the reactive process. However, it has not been investigated experimentally whether this assumption is justified for natural conditions.

The effectiveness of hydroxyapatite to fix soluble uranium (U) from a waste repository has been discussed by Gauglitz and Müller-Hoeppe. ${ }^{9}$ The authors came to the conclusion that phosphate bearing rocks are likely to immobilize $U$ released from natural or artificial deposits since phosphate bearing rocks tend to weather under those particular conditions (salinity, temperature) and form crystalline U compounds of very low solubility. In a similar way, before introducing reactive materials into a reactive barrier, it has to be ascertained that they will keep up their initial reactivity under field conditions for long periods of time. Furthermore, since in real life the reactants are often rock weathering products it is important 
to investigate the behaviour of various in situ generated reactants for conditions relevant in the field.

The remediation of $U$ contaminated soils (e.g. waste rocks derived from mining activities) is an urgent matter because they represent a potential long term source of contamination for the underlying groundwater under natural leaching conditions. In order to accurately predict the environmental impact of these soils, efforts have been made to understand the behavior of $U$ under water saturated conditions, especially its speciation and mobility with various inorganic and organic ligands. ${ }^{15,16}$ However, contradictory results have been reported. Particularly, when assessing the risk related to offsite $U$ transport, it is not yet known which processes (solubility of U-bearing minerals or sorption/desorption processes as measured by the $\mathrm{U}$ distribution coefficient $(\mathrm{Kd})$ in these soils) control $\mathrm{U}$ solubility of these soils. ${ }^{16,17}$ Almost all of these experiments have been conducted with leaching solutions $\left(\mathrm{H}_{2} \mathrm{C}_{2} \mathrm{O}_{4},\left(\mathrm{NH}_{4}\right)_{2} \mathrm{CO}_{3}\right.$, $\mathrm{Na}_{2} \mathrm{CO}_{3}, \mathrm{NaHCO}_{3} \ldots$ ) which are by far more aggressive than natural groundwaters. ${ }^{18}$ The present study aims at the characterization of $U$ release from a natural rock by tap water (as a proxy for seepage water) influenced by the presence of natural carbonate minerals for various experimental oxic and suboxic conditions. Under theses conditions, $\mathrm{U}$ is most likely to be present as carbonate- and hydroxyl-complexes. ${ }^{19,20}$ It is intended to obtain kinetic constants for local geochemical modelling.

The present study combines two systems of minerals with considerable dissolutions uncertainties together: a Ubearing rock and a reactive mineral (calcite, dolomite, pyrite or vaterite). Such an experiment is required to gain insight into the natural processes influencing $\mathrm{U}$ release under natural conditions. Major interest is focused on the effects of the presence of additional minerals, i.e. $\mathrm{FeS}_{2}, \mathrm{CaCO}_{3}, \mathrm{CaMg}\left(\mathrm{CO}_{3}\right)_{2}$, on the releasing efficiency of $\mathrm{U}$ from a well-characterised rock. All the materials were mixed with tap water in defined reaction vessels. The time dependence of the $\mathrm{U}$ release is discussed. 


\section{Experimental Section}

\section{Solid Materials}

The used U-bearing rock is a multi-mineralic rock from Slovenia (unknown location). Its chemical composition was determined by X-ray fluorescence (XRF - PW 2400, Philips, The Netherlands). This rock contains ca. $2.3 \% \mathrm{U}$, and is composed mainly of: $81.25 \% \mathrm{SiO}_{2}$, $0.14 \% \mathrm{TiO}_{2} ; 7.36 \% \mathrm{Al}_{2} \mathrm{O}_{3}, 1 \% \mathrm{Fe}_{2} \mathrm{O}_{3}, 0.01 \% \mathrm{MnO} ; 0.48 \% \mathrm{MgO}, 0.67 \% \mathrm{CaO}, 1.19 \%$ $\mathrm{Na}_{2} \mathrm{O}, 1.48 \% \mathrm{~K}_{2} \mathrm{O}, 0.36 \% \mathrm{P}_{2} \mathrm{O}_{5}$ and $0.01 \% \mathrm{SO}_{3}$. EDX analysis (results not shown) revealed that the used U-bearing rock is a multi-mineralic rock containing among others uraninite $\left(\mathrm{UO}_{2}\right)$, arsenopyrite (FeSAs), and galena $(\mathrm{PbS})$. Association of $\mathrm{U}$ with arsenopyrite was also encountered. The material was crushed and fractionated by sieving. The fraction 0.250 to $0.315 \mathrm{~mm}$ was used in this study without any further pre-treatment.

A pyrite mineral $\left(\mathrm{FeS}_{2}\right)$ from the Harz mountains (Germany) was crushed and sieved. The fraction $0.315 \mathrm{~mm}$ to $0.63 \mathrm{~mm}$ was used. The main elemental composition is: $\mathrm{Fe}: 40 \%, \mathrm{~S}$ : 31.4\%, Si: $6.7 \%, \mathrm{Cl}: 0.5 \%, \mathrm{C}: 0.15 \%$ (and $\mathrm{Ca}<0.01 \%$ ). The material served as a $\mathrm{pH}$ shifting reagent as well as iron oxide producer.

Carbonate minerals (from diverse locations) were crushed, sieved and the fraction 0.63 to $1.0 \mathrm{~mm}$ was used. Their chemical composition is given in Tab 1 . These minerals are known for carbonate bearing property and it is expected, that their differential dissolution characteristic (pKsp-value in Tab 1) will increase the kinetics of U release to various extent.

\section{Uranium release Experiments}

In order to determine the $\mathrm{U}$ release from the rock into the aqueous solution while taking into account the individual properties of the additives, five types of experiments have been set up for a duration of up to more than two years (782 days) in tap water: I) U rock on its own (reference), II) U rock + vaterite, III) U rock + calcite, IV) U rock + dolomite and V) U rock + pyrite (system I, II, III, IV and V; Tab 2). In the closed systems (non-homogenised batch experiments), the majority of the experiments were conducted with $8 \mathrm{~g} / \mathrm{L} \mathrm{U}$ rock and $8 \mathrm{~g} / \mathrm{L}$ 
additive, some experiments were conducted with $8,16,32$ or $48 \mathrm{~g} / \mathrm{L}$ of the correspondent additive (system III and IV; Tab 2). The air-homogenised batch experiments (open systems) were conducted with $10 \mathrm{~g} / \mathrm{L} \mathrm{U}$ rock and 0 or $15 \mathrm{~g} / \mathrm{L}$ of each additive for an experimental duration of up to 70 days.

Two different experimental procedures were adopted:

Non-homogenised batch experiments: $0.1 \mathrm{~g}$ of the uranium rock and $0.1 \mathrm{~g}$ of the additive (pyrite, vaterite, calcite or dolomite) were allowed to react in sealed glass sample tubes containing $13.0 \mathrm{~mL}$ of tap water at laboratory temperature (ca. $21^{\circ} \mathrm{C}$ ). The solid/solution ratios were $8 \mathrm{~g} / \mathrm{L}$ both for the $\mathrm{U}$ rock and the additive. For comparison, a further set of experiments was conducted with the $U$ rock alone (reference). The used tap water of the city of Jena (Thuringia, Germany) had a composition (in $\mathrm{mg} / \mathrm{L}$ ) of $\mathrm{Cl}^{-}: 15.3 ; \mathrm{NO}_{3}{ }^{-}: 10.0 ; \mathrm{SO}_{4}{ }^{2-}$ : 72.1; $\mathrm{HCO}_{3}^{-}: 268.0 ; \mathrm{Na}^{+}: 8.7 ; \mathrm{K}^{+}: 5.3 ; \mathrm{Mg}^{2+}: 29.3$ and $\mathrm{Ca}^{2+}: 80.9$ and an initial $\mathrm{pH}$ of 7.5. After a selected equilibration duration (14 to 782 days), $\leq 0.20 \mathrm{~mL}(\leq 200 \mu \mathrm{L})$ of the supernatant solution was retrieved from the top of each tube for uranium analysis without prior homogenisation of the sample by shaking or stirring. All experiments were performed in triplicate for each system.

Air-homogenised batch experiments: These experiments were conducted in special glass reaction vessels (ca. $125 \mathrm{~mL}$ capacity) allowing the system to be homogenised by a current of humid air (small aquaristic pump). ${ }^{22}$ The goal was to homogenise the experimental systems at atmospheric pressure without breaking down the materials (no communition). $1 \mathrm{~g}$ of the $\mathrm{U}$ rock and 0 or $1.5 \mathrm{~g}$ of the additive (pyrite or dolomite) were allowed to react in the sealed reaction vessels containing $100 \mathrm{~mL}$ of tap water at laboratory temperature $\left(21^{\circ} \mathrm{C}\right)$. The used tap water of the city of Göttingen (Lower Saxonia, Germany) had a composition (in $\mathrm{mg} / \mathrm{L}$ ) of $\mathrm{Cl}^{-}: 7.7 ; \mathrm{NO}_{3}^{-}: 10.0 ; \mathrm{SO}_{4}^{2-}: 37.50 ; \mathrm{HCO}_{3}^{-}: 88.45 ; \mathrm{Na}^{+}: 7.00 ; \mathrm{K}^{+}: 1.2 ; \mathrm{Mg}^{2+}: 7.5$ and $\mathrm{Ca}^{2+}: 36.0$ and an initial $\mathrm{pH}$ of 8.3 . At selected times ( $\leq 70$ days), $1.5 \mathrm{~mL}$ of the solution was retrieved 
for $\mathrm{U}$ analysis and the same volume of tap water was added to the system. The $\mathrm{pH}$ value and the redox potential were recorded at selected dates.

\section{Analytical Method}

Analysis for $\mathrm{U}$ was performed by inductively coupled plasma mass spectrome try (ICPMS) PQ3-S (Thermo Elemental, U.K). All chemicals used for experiments and analysis were of analytical grade. Uranium standard solutions were prepared from $1000 \mathrm{mg} / \mathrm{l} \mathrm{U}$ stock solution (Spex, Germany). Due to the excellent detection limits of ICP-MS satisfactory results for the concentration range of this study were obtained accompanied by low sample consumption (high dilution factors up to 400 could be used). The $\mathrm{pH}$ value was measured by combination glass electrodes (WTW Co., Germany). Electrodes were calibrated with five standards following a multi-point calibration protocol $^{23}$ and in agreement with the new IUPAC recommendation. ${ }^{24}$ Redox potentials are reported relative to the Standard Hydrogen Electrode (SHE).

Krypton adsorption isotherms at $77 \mathrm{~K}$ of the used Ubearing rock were measured with an Autosorb-1 instrument (Quantachrome). The specific surface area was calculated using the standard multipoint BET procedure ${ }^{25}$ with a cross sectional area of $20.5 \AA^{2}$ for Kr. Prior to measurements, the samples were degassed at $300^{\circ} \mathrm{C}$ for 1 hour.

\section{Results}

At any time after starting the experiments, the evolution of the systems was characterized by determining the aqueous $\mathrm{U}$ concentration (C). In closed systems, reported $\mathrm{C}$ values are mean values of individual triplicates. For each triplicate, the standard deviation ( $\sigma$, error bars in the figures) was calculated and the relative error $(100 * \sigma / \mathrm{C}$ in $\%)$ was deduced.

From both sets of experiments, the kinetic constant of the $U$ release was calculated according to the following equation. ${ }^{26,27}$ 


$$
\mathrm{C}=\mathrm{Co}\left[1-\mathrm{e}^{-\left(\mathrm{KL}_{\mathrm{L}} \mathrm{t} . \mathrm{O} / \mathrm{Co} . \mathrm{V}\right)}\right]
$$

$\mathrm{C}$ stands for the aqueous $\mathrm{U}$ concentration at time $\mathrm{t}$, Co for the saturation $\mathrm{U}$ concentration, $\mathrm{K}_{\mathrm{L}}$ for the kinetic constant, $\mathrm{O}$ for the effective surface area and $\mathrm{V}$ for the volume of the solution. The kinetic constants were obtained by a non-linear regression. The specific surface area of the used rock was determined at $3.53 \mathrm{~m}^{2} / \mathrm{g}$.

\section{Kinetics of $U$ release}

Non-homogenized batch experiments (closed systems)

The results of the kinetics of $U$ release are presented in Fig 1 (reference system). Generally, $U$ concentration $(\mathrm{C})$ increases continuously with time from the start of the experiment $(\mathrm{t}=0)$ to a maximum at $\mathrm{t}=564 \mathrm{~d}(54 \mathrm{mg} / \mathrm{L})$, afterwards $\mathrm{C}$ slowly decreases towards the end of the experiment (day 782). For $\mathrm{t} \leq 564 \mathrm{~d}$, the rate constant of $\mathrm{U}$ release was calculated from Eq 1 as $0.37 \pm 0.05 \mu \mathrm{gm}^{-2} \mathrm{~h}^{-1}$. Because of the small sample amounts, physicochemical parameters ( $\mathrm{pH}$ and Eh) were measured only once per triplicate at the end of the experiment (day 782). The $\mathrm{pH}$ varies between 7.8 and 8.4 and the Eh was almost constant with an average value of $340 \mathrm{mV}$. Therefore, the systems are oxic and aqueous $\mathrm{U}$ may be mostly available as U(VI) species.

\section{Air-homogenized batch experiments (open systems)}

The results of the kinetics of $U$ release are summarised in Fig 2 and Tab 3. Figure 2 shows that $\mathrm{C}$ increases continuously with time from the start of the experiment $(\mathrm{t}=0)$ to a maximum at $\mathrm{t}=50 \mathrm{~d}(8 \mathrm{mg} / \mathrm{L})$, afterwards $\mathrm{C}$ remains constant. The experiment was stopped after 70 days. The rate constant of $U$ release was calculated from Eq 1 as $0.78 \pm 0.11 \mu \mathrm{gm}^{-2} \mathrm{~h}^{-1}$. Table 3 summarises the variation of physicochemical parameters ( $\mathrm{pH}$ and $\mathrm{Eh}$ ) with the time. It can be seen that the $\mathrm{pH}$ value remains relative constant and close to 8.3 in system I and IV (reference and dolomite) but in system $\mathrm{V}$ (pyrite), the $\mathrm{pH}$ first decreases to a value of 6.3 and 
progressively increases to 8.0 at the end of the experiment. The Eh value was minimal at the beginning of the experiment in system $\mathrm{V}$ (pyrite) and then increases to values $>380 \mathrm{mV}$. Generally, the Eh value varies between 360 and $445 \mathrm{mV}$ in all the systems without any noticeable trend in the time dependency of its variation.

The characterization and differentiation of individual processes (adsorption, complexation, precipitation) responsible for the evolution of $\mathrm{C}$ under the experimental conditions (open and closed systems) of this work is not possible. However, the objective of this study is not to accurately define the systems in which the materials (U-bearing rock, pyrite and $\mathrm{CO}_{3}{ }^{2-}-$ minerals) are involved, but rather to qualitatively characterize the effect of the minerals on $U$ solubilization. Therefore, the evolution of other systems (system II, III, IV and V) will be compared with that of the reference system (system I) while characterising system evolution by the trend in the variation of $\mathrm{C}$, the experimental and the modelled saturation concentrations $\left(\mathrm{C}_{\mathrm{sat}}\right.$ and $\left.\mathrm{Co}\right)$ and the rate of $\mathrm{U}$ release $\left(\mathrm{K}_{\mathrm{L}}\right)$.

\section{Effect of the additives in closed systems}

Table 4, Fig 1 and Fig 3 summarize the results of the $U$ release from the Ubearing rock in non-homogenised batch experiments. Table 4 summarizes the $U$ concentration $(C)$ and the percent $\mathrm{U}$ release $(\mathrm{P})$ of the systems for 14, 564 and 782 days (start, saturation and end of the experiment). As discussed elsewhere, ${ }^{28}$ the relative error of the triplicates was minimal at saturation. Figure 1 shows the evolution of the systems as a function of time. It is apparent that saturation is achieved after ca. 564 days in all systems. Figure 3 compares the efficiency of $\mathrm{U}$ release in the systems with $8 \mathrm{~g} / \mathrm{L}$ of additive for 14 and 564 days

These results can be summarized as follows:

- Only ca. $30 \%$ of total amount of $U$ of the rock could be leached under the applied experimental conditions; 
- none of the additives could significantly enhance the $U$ release from the Ubearing rock during the whole experimental period (Tab 4);

- U release efficiency is significantly reduced in the presence of calcite (Fig 1) and pyrite (Fig 3a);

- the variation of the standard deviations of the triplicates in the initial phase is very large (up to $106 \%$ );

- no trend in the effectiveness order of carbonate minerals with respect to their amount or their solubility could be observed (Tab 4, Fig 3a);

- at saturation (564 days), the effectiveness order was the following for the systems with $8 \mathrm{~g} / \mathrm{L}$ additive $:$ calcite $<$ reference $<$ vaterite $<$ dolomite (Fig 3b); for system III: III < IIIa $<$ IIIc < IIIb; and for system IV: IV $_{c}<$ IV.

- the absolute aqueous $U$ concentrations at saturation varied between $50 \mathrm{mg} / \mathrm{L}$ for calcite and $58 \mathrm{mg} / \mathrm{L}$ for dolomite (Tab 4);

- the kinetic parameters were calculated according to Eq 1 and are summarised in Tab 5. The results confirm that calcite (system III) significantly lowers the kinetics of U release;

- the comparison of modelled and experimental saturation concentrations ( Co and $\left.\mathrm{C}_{\mathrm{sat}}\right)$ shows that Co is 1.2 to 2.3 times larger than $\mathrm{C}_{\text {sat }}$. These results exemplify the difficulty of modelling contaminant release from complex natural systems;

- the value of the kinetic constants varied between 0.27 and $0.48 \mu \mathrm{gm}^{-2} \mathrm{~h}^{-1}$ and the relative error was ca. $14 \%$.

In closed and non-homogenised batch experiments, diffusion is the limiting factor in the mechanism of $U$ release in to the aqueous phase. Even though quasi-stagnant conditions are not a rule in the real world, situations exist where such conditions are permanent, such as groundwater inflowing in an area of the subsurface is faster than the outflow. Such a situation 
may be encountered in a reactive permeable walls as the hydraulic conductivity decreases as result of mineral precipitations. ${ }^{29,30}$

\section{Effect of the additives in open systems}

Figure 2 summarizes the results of the $U$ release from the rock for 70 days in the airhomogenised batch experiments for systems I (reference), IV (dolomite) and V (pyrite) (see Tab 2). The results can be summarized as follows:

- the effectiveness order of $U$ release is: pyrite < reference < dolomite;

- during the first two weeks, no significant difference between systems I (reference) and IV (dolomite) could be observed with an obvious difference to system V (pyrite);

- after ca. 5 days the U concentration progressively increases in system V (pyrite) and reaches that of the reference system (system I) after 70 days.

- in system IV (dolomite), a further U concentration increase was observed after 14 days and no steady state was achieved at the end of the experiment (70 d);

- at the end of the experiment (day 70), ca. $50 \%$ of the initial amount of U was leached in the system IV (dolomite) whereas the leaching efficiency for systems I and V was ca. $35 \%$ (vs. $30 \%$ at saturation in closed systems);

- the saturation concentration was ca. $8 \mathrm{mg} / \mathrm{L} \mathrm{U}(0.035 \mathrm{mM})$ in system I;

- the kinetic parameters were calculated from the experimental results, according to equation 1 and are summarized in Tab 6. The value of the kinetic constants varied between 0.21 and $0.78 \mu \mathrm{gm}^{-2} \mathrm{~h}^{-1}$ and the relative error varies between 5 and $14 \%$.

\section{Discussion}

The evolution of the $U$ concentration in the individual systems results from at least five concurring processes: (1) U leaching from rock, (2) formation of soluble complexes between 
$\mathrm{U}(\mathrm{VI}), \mathrm{Ca}^{2+}$ and $\mathrm{CO}_{3}{ }^{2-} ;{ }^{15,31,32}$ (3) $\mathrm{U}$ sorption onto rock by-minerals (e.g. $\mathrm{Al}_{2} \mathrm{O}_{3}, \mathrm{SiO}_{2}$ ) and the reaction vessel (glass); ${ }^{18,28}$ (4) $\mathrm{U}$ incorporation into the mineral structure; ${ }^{33}$ and (5) $\mathrm{U}$ precipitation from the aqueous phase (e.g. as $\mathrm{UO}_{3} \cdot 2 \mathrm{H}_{2} \mathrm{O}, \mathrm{UO}_{2} \mathrm{CO}_{3}$ ). It can be concluded that, during the first phase of the experiment $[0 \leq t(d) \leq 564$ in closed systems and $t<50 \mathrm{~d}$ in open systems], $\mathrm{U}$ releasing processes dominate (process 1 and 2). At t $>564 \mathrm{~d}$ (closed systems), since $\mathrm{U}$ concentration decreases $\mathrm{U}$ precipitation dominates.

In the system with pyrite (system $\mathrm{V}$ ), $\mathrm{U}$ release is inhibited in the early phase of the experiment ( $t<5 \mathrm{~d}$ in Fig 2). The most probable reason for this inhibition is the formation of iron (oxy)hydroxides [e.g. $\mathrm{Fe}(\mathrm{OH})_{3 \mathrm{am}}$ ], which is a well known $\mathrm{U}$ sorbent. ${ }^{34,35}$ Thus, in the initial phase, the kinetics of iron hydroxide production is faster than that of $U$ release. The released $U$ is completely adsorbed onto (or co-precipitated with) in-situ formed $\mathrm{Fe}(\mathrm{OH})_{3 \mathrm{am}}$ and is therefore not available in the bulk solution until the sorption capacity of the iron oxide is exhausted.

In open systems, dolomite clearly enhanced the kinetics of $U$ release. This increase of $U$ concentration (Fig 2) primary results from the $\mathrm{HCO}_{3}{ }^{-} / \mathrm{CO}_{3}{ }^{2-}$ production from the dolomite dissolution. In contrast, in closed systems, only slight differences were observed between the systems with carbonate minerals, although they are different with regard to the solubility $\left(\log K_{s p}\right.$ values in Tab 1). These differences were primary attributed to the differential ability of individual minerals to incorporate $\mathrm{U}(\mathrm{VI})$-species in their structure (ref 33 and references therein). The inhibition of the kinetics of $U$ release by $8 \mathrm{~g} / \mathrm{L}$ calcite was interpreted as insufficient carbonate and calcium production for complex formation with $\mathrm{U}^{31,32}$ since no such inhibition was observed in systems with higher calcite amount (16 to $48 \mathrm{~g} / \mathrm{L}$ ). If adsorption or incorporation were the determining processes, systems with higher calcite amounts should have exhibited lower $\mathrm{U}$ release kinetics. ${ }^{28}$

From the discussion above, more $\mathrm{U}$ has been leached in the presence of pyrite (system V) and a part has been fixed by in-situ formed iron oxides. A steady state concentration of 
approximately $8 \mathrm{mg} / \mathrm{L} \mathrm{U}(0.035 \mathrm{mM})$ in system $\mathrm{I}$ can be considered as maximum concentration for surface water having a composition close to that of the tap water of Göttingen. This assumption is justified by the fact that drinking water is generally a natural water with artificially reduced $\mathrm{Fe}$ and $\mathrm{Mn}$ concentrations. If the water was richer in $\mathrm{Fe}$ and Mn the formation of the corresponding oxides would have initiated $U$ sorption thereby lowering the $\mathrm{U}$ concentration at steady state. In contrast, if the subsurface had an elevated partial pressure of $\mathrm{CO}_{2}$ (e.g. as result of microbial activity) the resulting effect would be elevated $\mathrm{U}$ concentrations in the effluents as demonstrated in the experiment with dolomite (system IV), which is in accordance with literature. ${ }^{15}$

The comparison of modelled and experimental kinetic constants (Tab 5 and 6) shows that the errors in values of $\mathrm{C}_{0}$ and $\mathrm{K}_{\mathrm{L}}$ are smaller in open systems (6 to $14 \%$ vs. 14 to $41 \%$ ). It is interesting to note that in systems I and IV the ratio of the modelled saturation concentrations $\left(\mathrm{C}_{0}\right)$ and the concentrations at the end of the experiment ( $\mathrm{C}$ at day 70$)$ was almost 1 , even though a steady state was achieved only in system $\mathrm{I}$. The ratio $\mathrm{C}_{0} / \mathrm{C}>1.7$ for system $\mathrm{V}$ (pyrite) was attributed to the sorption properties of $\mathrm{Fe}(\mathrm{OH})_{3 \mathrm{am}}$ produced at the beginning of the experiment (Fig 3). The agreement between modelled and experimental $U$ saturation concentrations for system $\mathrm{I}\left(\mathrm{C}_{0} / \mathrm{C}=1\right)$ validates the basic assumptions of Eq $1 .^{26}$ The above results show the difficulty of predicting the leaching rate of a U-bearing rock under natural conditions. Two extreme cases were considered for the investigation of chemical weathering by tap water used as a proxy for natural seepage water: a closed system $\left(\mathrm{P}<\mathrm{P}_{\mathrm{atm}}\right)$ and a system in equilibrium with the atmosphere $\left(\mathrm{P}=\mathrm{P}_{\mathrm{atm}}\right)$. In the subsurface however, none of these cases will strictly be encountered. Furthermore, in the majority of natural systems, the conditions will vary with climate (temperature, depth of the water table), season, degree of saturation of the soil, heterogeneity of the subsurface, presence of reactive materials, solution chemistry and of course with type and degree of previous physical weathering. Altogether these factors will complicate any attempt for prediction. 


\section{Implications for future research}

The presented study has shown that for a well defined experimental set-up, an accurate determination of local parameters can enable the determination of more realistic parameters for regional modelling purposes. At each specific site, the chemical environment is readily disrupted by circulating subsurface (ground-)water. Thus, the tendency of chemical weathering toward a new static steady state as the one described here is opposed by complex reduction reactions due to biological activities of plants and microorganisms. ${ }^{36}$ It needs to be emphasized that physical processes (e.g. unloading, thermal expansion, crystal growth) also influence the weathering process but their influence is insignificant in comparison with that of chemical alteration. Nevertheless, these physical processes are important in rendering rocks more susceptible to chemical attack than they would be otherwise. ${ }^{36,37}$ Among the six possible individual chemical reactions responsible for weathering processes (solution and colloid formation, hydration, hydrolysis, oxidation, reduction, and exchange reactions; e.g. ref 36), redox reactions could not be addressed in this work since the experiments were conducted under oxic conditions (Tab. 3: $324 \leq \mathrm{Eh} \leq 445$ ). Under these conditions aqueous uranium is available as U(VI) complexes. Under field conditions however, their importance will depend on the geochemical conditions.

Table 7 compares the experimental solubilization parameters at equilibrium $\left(\mathrm{C}_{\mathrm{sat}}\right.$ and $\left.\mathrm{K}_{\mathrm{L}}\right)$ of this work with literature data on schoepite under oxic conditions. From table 7 it can be seen that: (1) synthetic schoepite is more soluble than natural schoepite; (2) natural U-bearing rock exhibits the lowest $\mathrm{K}_{\mathrm{L}}$-value, (3) for the $\mathrm{U}$ rock, the lowest $\mathrm{K}_{\mathrm{L}}$-value is obtained in nonhomogenised batch experiments whereas the lowest saturation concentration is obtained in air-homogenised batch experiments. Both values of the saturation concentration ( 8 and 54 $\mathrm{mg} / \mathrm{L})$ are considerably larger than the solubility limit of schoepite around $\mathrm{pH} 7\left(10^{-5} \mathrm{M}\right.$ or 2.4 $\left.\mathrm{mgL}^{-1},{ }^{20}\right)$ but comparable to reported field data, ${ }^{10,40}$ attesting the ability of the experimental 
procedure to simulate natural scenarios. Keeping in mind that the used U-bearing rock contents $81 \% \mathrm{SiO}_{2}$, its $\mathrm{K}_{\mathrm{L}}$-value $\left(0.45\right.$ or $\left.0.78 \mu \mathrm{g} \cdot \mathrm{m}^{-2} \cdot \mathrm{h}^{-1}\right)$ can be compared to that of pure amorphous $\mathrm{SiO}_{2}\left(0.17 \mu \mathrm{g} \cdot \mathrm{m}^{-2} \cdot \mathrm{h}^{-1}\right)$ reported by $\mathrm{Xu}$ and Pruess. ${ }^{41}$ Faimon $^{42}$ presents a compilation of dissolution data on quartz dissolution rates at neutral $\mathrm{pH}$ values. This compilation shows that the dissolution of quartz is more than three orders of magnitude lower than the value for amorphous $\mathrm{SiO}_{2}$ from Xu and Pruess ${ }^{41}$ (2000). This discussion shows that the solubility of $\mathrm{U}$ from a natural rock may be closer to the solubility of the matrix (here $\mathrm{SiO}_{2}$ ) than to the solubility of a pure phase (here schoepite). Therefore, the use of solubility limits based on pure solid phases may be an unacceptable approximation. ${ }^{43,44}$ Moreover, instead of dissolution rate constants of pure solid phases, $\mathrm{K}_{\mathrm{L}}$-values from relevant U-bearing minerals can be determined and used for regional modelling purposes. In nature, the migration of leached $\mathrm{U}$ will primary depend on local chemical composition of groundwater $(\mathrm{pH}$ and redox potential, competing cations and available ligands, nature of soils).

The presented results revealed that, only 30 to $50 \%$ of the total amount of $U$ in the rock could be leached under the experimental conditions. The solubilization kinetics of the remaining 50 to $70 \%$ is by no means linear since it primarily depends on the weathering behavior of the rock matrix. Therefore, predicting the service time of treatment installations down gradient of mine tailings is very difficult both from the aspect of contaminant release and of reactive material reactivity in the long term. If the reactive material is a rock, solubilisation problems discussed here (for a contaminant) will be encountered.

\section{Conclusion}

In this study the leaching process of $U$ from a natural rock as influenced by reactive minerals (vaterite, calcite, dolomite or pyrite) was characterized by two different types of experiments: open and closed syste ms. 
- Under atmospheric conditions (open systems) a steady state was achieved within 50 days, the leaching efficiency was $35 \%$ of the initial $U$ content of the rock and a good agreement between experimental and modelled saturation concentration was found.

- In closed systems a steady state was achieved within 564 days (1.5 years), $30 \%$ of the initial $U$ content of the rock could be leached and the accuracy of the modelled equilibrium parameters $\left(\mathrm{Co}\right.$ and $\left.\mathrm{K}_{\mathrm{L}}\right)$ was considerably lower.

- None of the reactive minerals could significantly enhance the leaching efficiency of $U$ in closed system. In open systems dolomite considerably enhances U leaching efficiency $(50 \%)$.

- The results of this study suggest that $\mathrm{U}$ release from ore and waste rocks can be better modelled by considering the nature of the rock matrix.

- Generally, before any material (rock, mineral) can be used as solubility controlling phase for remediation purposes, one should ascertain that it will weather for long time periods under the actual site specific conditions.

\section{Acknowledgments}

This work was supported by the German Science Foundation (Deutsche Forschungsgemeinschaft; DFG-Sa 501/15-1).

\section{References}

1. P.-K. LeE, M.-J. Kang, S.-H. ChOI, J.-C. Touray, Appl. Geochem. 20 (2005) 1687.

2. W. Stumm, J.J. Morgan, Aquatic chemistry, John Wiley \& Sons, Inc, 1996, p. 1022.

3. M.A. Williamson, J.D. Rimstidt, Geochim. Cosmochim. Acta 58 (1994) 5443.

4. R.V. Nicholson, R.W. Gillham, E.J. Reardon, Acta 52 (1998) 1077.

5. B. Strömberg, S. BANWART, J. Contam. Hydrol. 39 (1999) 59.

6. J.S. Arey, J.C. SeAman, M.P. Bertsch, Environ. Sci. Technol. 33 (1999) 337. 
7. D.W. Blowes, C.J. Ptacek, S.G. Benner, W.T. Mcrae Che, T.A. Bennett, R.W. PULS, J. Cont. Hydrol. 40 (2000) 123.

8. R. Gauglitz, M. Holterdorf, W. Franke, G. MarX, Radiochim. Acta 58 (1992) 253.

9. R. Gauglitz, N. MüLleR-HoePPe, Ein neuer Ansatz zur Bewertung der Wirksamkeit von Barrieren im Endlager (02 E 9087). Grundlage der Bewertung von Hydroxylapatit als chemische Barriere gegenüber Schwermetallen. Abschlußbericht Technischer Anhang 3. Deutsche Gesellschaft zum Bau und Betrieb von Endlagern für Abfallstoffe mbH. Peine (DE); Bundesministerium für Bildung. Wissenschaft. Forschung und Technologie. Bonn (DE) 1999.

10. J.L. JERDEN JR., A.K. SinHA, Appl. Geochem. 18 (2003) 823.

11. Q.Y. MA, S.J. Traina, T.J. LogAN, Environ. Sci. Technol. 27 (1993) 1803.

12. Q.Y. MA, T.J. LogAn, S.J. TRAINA, Environ. Sci. Technol. 28 (1994) 408.

13. Q.Y. MA, S.J. Traina, T.J. LogAn, J.A. RYAN, Environ. Sci. Technol. 28 (1994) 1219.

14. Q.Y. MA, T.J. LogAn, S.J. TRAINA, Environ. Sci. Technol. 29 (1995) 1118.

15. D. LANGMUIR, Aqueous Environmental Geochemistry. Prentice Hall, 1997, pp. 600.

16. M.P. ELLESS. S.Y. LEE, Water, Air, and Soil Pollut. 107 (1998) 147.

17. D.I. KAPLAN, S.M. SERKIZ, J. Radioanal. Nucl. Chem. 248 (2001) 529.

18. C. NoubacteP, J. SONNENFELD, M. SAUTER, Grundwasser 10 (2005) 35.

19. A. MeinRath, P. Schneider, G. MeinRath, J. Environ. Radioact. 64 (2003) 175.

20. C. Noubactep, G. Meinrath, P. Dietrich, B. Merkel, Environ. Sci. Technol. 37 (2003) 4304.

21. W. Stumm, Chemistry of the solid-water interface. John Wiley \& Sons, New York, 1992, p. 428.

22. C. NOUBACTEP, Untersuchungen zur passiven in-situ-Immobilisierung von U(VI) aus Wasser. Dissertation, TU Bergakademie Freiberg, Wiss. Mitt. Institut für Geologie der TU Bergakademie Freiberg, Band 21 (2003) 140 pp. 
23. G. MeinRATH, P. SPITZER, Mikrochim. Acta 135 (2000) 155.

24. R.P. Buck, S. Rondinini, A.K. Covington, F.G.K. Baucke, C.M.A. Brett, M.F. Camoes, M.J.T. Milton, T. Mussini, R. Naumann, K.W. Pratt, P. Spitzer, G.S. WiLson, Pure Appl. Chem. 74 (2002) 2169.

25. S. Brunauer, P. Emmett, E. Teller, J. Am. Chem. Soc. 60 (1938) 309.

26. W. Vogelsberger, T. Mittelbach, A. Seidel, Ber. Bunsenges. Phys. Chem. 100 (1996) 1118.

27. M. Löbbus, W. Vogelsberger, J. Sonnefeld, A. SeIdel, Langmuir 14 (1998) 4386.

28. C. Noubactep, D. Merten, T. Heinrichs, J. Sonnefeld, M. Sauter, In Merkel BJ, Hasche-Berger A. (Eds.) Uranium in the Environment. Springer, Berlin, Heidelberg; 2005,425

29. P.D. MackenziE, D.P. Horney, T.M. SivaveC, J. Hazard. Mater. 68 (1999) 1.

30. R.T. WILKIN, R.W. PULS, G.W. SEWELL, Ground Water 41 (2003) 493.

31. G. Bernhard, G. GeiPel, V. Brendler, H. Nitsche, Radiochim. Acta 74 (1996) 87.

32. G. Bernhard, G. Geipel, T. Reich, V. BREndler, S. Amayri, H. Nitsche, Radiochim. Acta 89 (2001) 511.

33. R.J. Reeder, M. Nugent, G.M. Lamble, C.D. Tait, D.E. Morris, Environ. Sci. Technol. 34 (2000) 638.

34. C.H. Ho, N.H. MiLleR, J. Colloid Interface Sci. 110 (1986) 165.

35. D. LANGMUIR, Geochim. Cosmochim. Acta 42 (1978) 547.

36. P. REICHE, A survey of weathering processes and products. University of New Mexico Press; Albuquerque, 1950, p. 95.

37. M. Malmström, S. B anwart, J. Lewenhagen, L. Duro, J. Bruno, J. Cont. Hydrol. 21 (1996) 201. 
38. I. Casas, J. Bruno, E. Cera, R.J. Finch, R.C. Ewing, Kinetic and thermodynamic studies of uranium minerals: assessment of the long-term evolution of spent nuclear fuel, SKB report, 1994 pp. 73.

39. D. GAMMAR, Geochemistry of uranium at mineral-water interfaces: rates of sorptiondesorption and dissolution-precipitation reactions. Dissertation, California Institute of Technology, 2001, 277 pp.

40. M. Junghans, C. Helling, Historical mining, uranium tailings and waste disposal at one site: can it be managed? A hydrogeological analysis. In Tailings and Mine Waste '98, Balkema, Rotterdam, 1998, 117.

41. T. XU, K. PRUESS, Hydrothermal fluid flow and mineral alteration in a fractured rock under multiphase $\mathrm{H}_{2} \mathrm{O}-\mathrm{CO}_{2}$ mixture conditions. Proceedings World Geothermal Congress 2000 (Kyushu - Tohoku, Japan), 2000, 2983.

42. J. FAIMON, Aquatic Geochem. 11 (2005) 139.

43. R. GRAUER, Solubility Limitations: An “Old Timer's” View. In Grenthe I, Puigdomenech I. (Ed) Modelling in aquatic chemistry. OECD Publications, 1997, 131.

44. M.J. WILsON, Clay Miner. 39 (2004) 233. 
Table 1: Chemical composition of the carbonate minerals used determined by X-ray fluorescence $(\mathrm{XRF}) . \log \mathrm{K}_{\mathrm{sp}}$ is the logarithm of the solubility constant for pure phases.

\begin{tabular}{cccccccc}
\hline & $\mathrm{SiO}_{2}$ & $\mathrm{Al}_{2} \mathrm{O}_{3}$ & $\mathrm{Fe}_{2} \mathrm{O}_{3}$ & $\mathbf{M g O}$ & $\mathbf{C a O}$ & $\mathrm{Na}_{2} \mathrm{O}$ & $-\operatorname{logK}_{\mathbf{p}}{ }^{(\mathbf{a})}$ \\
\cline { 2 - 8 } & $(\%)$ & $(\%)$ & $(\%)$ & $(\%)$ & $(\%)$ & $(\%)$ & \\
\hline Vaterite & 0.5 & 0.1 & 0.1 & 1.12 & 55.0 & 0.06 & 7.73 \\
Calcite & 0.3 & 0.1 & 0.09 & 1.02 & 55.1 & 0.07 & 8.43 \\
Dolomite & 1.2 & 0.4 & 0.6 & 20.24 & 30.9 & 0.04 & 17.09 \\
\hline
\end{tabular}

(a) Values from ref. 21 
Table 2: Description and codification of the five investigated systems (nine experiments).

Non-homogenised batch experiments were conducted for all nine systems, whereby the experiment with System V was stopped after 14 days. Air-homogenised experiments were conducted with systems I, IV and V.

\begin{tabular}{ccccc}
\hline System & Additive & $\begin{array}{c}\text { [Additive] } \\
(\mathrm{g} / \mathrm{L})\end{array}$ & Code & Duration \\
& & 0 & & $($ days $)$ \\
\hline System I & no & I & 70,782 \\
System II & Vaterite & 8 & II & 782 \\
System III & Calcite & $8,16,32,48$ & $\mathrm{III}_{1} \mathrm{III}_{\mathrm{a}}, \mathrm{III}_{\mathrm{b}}, \mathrm{III}_{\mathrm{c}}$ & 782 \\
System IV & Dolomite & 8,48 & $\mathrm{IV}, \mathrm{IVc}$ & 70,782 \\
System V & Pyrite & 8 & $\mathrm{~V}$ & 70,14 \\
\hline
\end{tabular}


Table 3: Variations of the physicochemical parameters ( $\mathrm{pH}$ and $\mathrm{Eh}$ ) with the time in the three systems in air-homogenised batch experiments.

\begin{tabular}{ccccccc}
\hline Time & \multicolumn{2}{c}{ System I } & \multicolumn{2}{c}{ System IV } & \multicolumn{2}{c}{ System V } \\
\hline & $\mathrm{pH}$ & $\mathrm{Eh}$ & $\mathrm{pH}$ & $\mathrm{Eh}$ & $\mathrm{pH}$ & Eh \\
(days) & & $(\mathrm{mV})$ & & $(\mathrm{mV})$ & & $(\mathrm{mV})$ \\
\hline $\mathbf{0 . 1}$ & $8.3_{3}$ & 366 & $8.3_{1}$ & 441 & $6.3_{8}$ & 324 \\
$\mathbf{0 . 5}$ & $8.2_{9}$ & 441 & $8.2_{7}$ & 428 & $7.7_{1}$ & 381 \\
$\mathbf{1 . 0}$ & $8.3_{1}$ & 324 & $8.3_{2}$ & 426 & $7.5_{4}$ & 466 \\
$\mathbf{2 . 0}$ & $8.2_{2}$ & 445 & $8.2_{5}$ & 439 & $7.5_{1}$ & 461 \\
$\mathbf{4 . 0}$ & $8.3_{1}$ & 433 & $8.3_{1}$ & 442 & $7.7_{6}$ & 453 \\
$\mathbf{7 . 1}$ & $8.2_{6}$ & 411 & $8.2_{7}$ & 439 & $7.8_{4}$ & 455 \\
$\mathbf{1 3 . 0}$ & $8.3_{5}$ & 432 & $8.3_{6}$ & 433 & $7.9_{7}$ & 429 \\
$\mathbf{2 5 . 0}$ & $8.3_{4}$ & 435 & $8.3_{4}$ & 441 & $7.9_{9}$ & 441 \\
$\mathbf{5 5 . 0}$ & $8.2_{7}$ & 429 & $8.2_{5}$ & 437 & $7.9_{5}$ & 457 \\
$\mathbf{7 0 . 0}$ & $8.2_{8}$ & 402 & $8.2_{5}$ & 409 & $8.0_{0}$ & 433 \\
\hline
\end{tabular}


Table 4: Variation of the $U$ concentration $(C)$ and the percentage of $U$ release $(P)$ in nonhomogenised batch experiments for 14, 564 (saturation) and 782 days as function of the additive material. For codification see table 2.

\begin{tabular}{ccccccc}
\hline System & \multicolumn{2}{c}{ 14 days } & \multicolumn{2}{c}{ 564 days } & \multicolumn{2}{c}{ 782 days } \\
& C & $\mathrm{P}$ & $\mathrm{C}$ & $\mathrm{P}$ & $\mathrm{C}$ & $\mathrm{P}$ \\
& $(\mathrm{mg} / \mathrm{L})$ & $(\%)$ & $(\mathrm{mg} / \mathrm{L})$ & $(\%)$ & $(\mathrm{mg} / \mathrm{L})$ & $(\%)$ \\
II & $0.91 \pm 0.96$ & $0.5 \pm 0.5$ & $56 \pm 4$ & $32 \pm 3$ & $47 \pm 5$ & $27 \pm 3$ \\
III & $0.45 \pm 0.06$ & $0.3 \pm 0.1$ & $50 \pm 1$ & $28 \pm 1$ & $41 \pm 1$ & $23 \pm 1$ \\
IIIa & $0.63 \pm 0.12$ & $0.4 \pm 0.1$ & $55 \pm 2$ & $31 \pm 1$ & $44 \pm 7$ & $25 \pm 2$ \\
IIIb & $0.48 \pm 0.11$ & $0.3 \pm 0.1$ & $56 \pm 3$ & $32 \pm 2$ & $48 \pm 5$ & $27 \pm 3$ \\
IIIc & $0.40 \pm 0.11$ & $0.2 \pm 0.1$ & $56 \pm 4$ & $32 \pm 2$ & $48 \pm 1$ & $27 \pm 1$ \\
IV & $0.55 \pm 0.12$ & $0.3 \pm 0.1$ & $58 \pm 5$ & $34 \pm 3$ & $53 \pm 6$ & $30 \pm 3$ \\
IVc & $0.50 \pm 0.06$ & $0.3 \pm 0.1$ & $57 \pm 6$ & $32 \pm 4$ & $49 \pm 4$ & $28 \pm 3$ \\
\hline
\end{tabular}


Table 5: Recapitulation of the experimental aqueous $U$ saturation concentrations $\left(\mathrm{C}_{\mathrm{sat}}\right)$, the modelled saturation concentrations $(\mathrm{Co})$ and the modelled kinetic constants $\left(\mathrm{K}_{\mathrm{L}}\right)$ and their standard deviation $(\sigma)$ for non-homogenised batch experiments. $\mathrm{Co} / \mathrm{C}_{\mathrm{sat}}$ is the correspondent ratio of modelled to experimental $\mathrm{U}$ saturation concentration. See table 2 for the codification of the systems.

\begin{tabular}{|c|c|c|c|c|c|c|c|}
\hline \multirow[t]{2}{*}{ System } & \multicolumn{2}{|c|}{$\begin{array}{c}\mathbf{K}_{\mathbf{L}} \\
\left(\mu \mathrm{g} \cdot \mathrm{m}^{-2} \cdot \mathrm{h}^{-1}\right)\end{array}$} & \multicolumn{2}{|c|}{$\begin{array}{c}\text { Co } \\
\left(\mathrm{mg} \cdot \mathrm{L}^{-1}\right)\end{array}$} & \multicolumn{2}{|c|}{$\begin{array}{c}\mathbf{C}_{\text {sat }} \\
\left(\mathrm{mg} . \mathrm{L}^{-1}\right)\end{array}$} & \multirow[t]{2}{*}{$\mathrm{Co} / \mathrm{C}_{\text {sat }}$} \\
\hline & value & $\sigma$ & value & $\sigma$ & value & $\sigma$ & \\
\hline I & 0.37 & 0.05 & 78.0 & 14.7 & 53.9 & 2.1 & 1.4 \\
\hline II & 0.48 & 0.08 & 68.0 & 9.8 & 56.1 & 4.4 & 1.2 \\
\hline III & 0.27 & 0.04 & 115.3 & 53.3 & 50.1 & 0.8 & 2.3 \\
\hline IV & 0.38 & 0.05 & 101.4 & 26.1 & 59.7 & 4.5 & 1.7 \\
\hline IIIa & 0.32 & 0.05 & 103.4 & 36.9 & 54.7 & 2.1 & 1.9 \\
\hline IIIb & 0.33 & 0.05 & 111.7 & 46.0 & 56.0 & 3.0 & 2.0 \\
\hline IIIc & 0.35 & 0.05 & 93.7 & 25.3 & 56.5 & 3.9 & 1.7 \\
\hline IVc & 0.42 & 0.07 & 80.6 & 18.3 & 56.9 & 6.2 & 1.4 \\
\hline
\end{tabular}


Table 6: Recapitulation of experimental $\left(\mathrm{C}_{\mathrm{sat}}\right)$ and modelled $\left(\mathrm{C}_{0}\right)$ aqueous $\mathrm{U}$ saturation concentrations, the modelled kinetic constants $\left(\mathrm{K}_{\mathrm{L}}\right)$ and their standard deviation $(\sigma)$ for air-homogenised batch experiment (70 days). The correspondent $\mathrm{Co} / \mathrm{C}_{\mathrm{sat}}{ }^{-\mathrm{values}}$ are given. See table 2 for the codification.

\begin{tabular}{|c|c|c|c|c|c|c|}
\hline \multirow[t]{2}{*}{ System } & \multicolumn{2}{|c|}{$\begin{array}{c}\mathbf{K}_{\mathbf{L}} \\
\left(\mu \mathrm{g} \cdot \mathrm{m}^{2} \cdot \mathrm{h}^{-1}\right)\end{array}$} & \multicolumn{2}{|c|}{$\begin{array}{c}\mathbf{C}_{\mathbf{0}} \\
\left(\mathrm{mg} \cdot \mathrm{L}^{-1}\right)\end{array}$} & \multirow[t]{2}{*}{$\begin{array}{c}\mathbf{C}_{\text {sat }} \\
\left(\mathrm{mg} \cdot \mathrm{L}^{-1}\right)\end{array}$} & \multirow[t]{2}{*}{$\mathrm{Co} / \mathrm{C}_{\mathrm{sat}}$} \\
\hline & value & $\sigma$ & value & $\sigma$ & & \\
\hline I & 0.78 & 0.11 & 7.45 & 0.48 & 8.32 & 0.9 \\
\hline IV & 0.69 & 0.08 & 11.34 & 0.81 & 11.77 & 1.0 \\
\hline V & 0.21 & 0.01 & 13.72 & 1.93 & 8.28 & 1.7 \\
\hline
\end{tabular}


Table 7: Comparison between experimental equilibrium parameters for $U$ solubilization [saturation concentrations $\left(\mathrm{C}_{\mathrm{sat}}\right)$ and dissolution kinetic constants $\left(\mathrm{K}_{\mathrm{L}}\right)$ ] of this study with literature data on schoepite. In addition, initial $\mathrm{pH}$ values are included.

\begin{tabular}{lcccl}
\hline Material & $\mathbf{p H}$ & $\begin{array}{c}\mathbf{C}_{\text {sat }} \\
\left(\mathrm{mg} \cdot \mathrm{L}^{-1}\right)\end{array}$ & $\begin{array}{c}\mathbf{K}_{\mathbf{L}} \\
\left(\mu \mathrm{g} \cdot \mathrm{m}^{-2} \cdot \mathrm{h}^{-1}\right)\end{array}$ & Reference \\
\hline U-rock $^{(\mathrm{a})}$ & 7.8 & 54 & 0.45 & this work \\
U-rock $^{(\mathrm{b})}$ & 8.3 & 8 & 0.78 & this work \\
$\mathbf{U O}_{\mathbf{3}} \cdot \mathbf{2} \mathbf{H}_{\mathbf{2}} \mathbf{O}^{(\mathrm{c})}$ & - & - & 5.0 & $38^{(\mathrm{d})}$ \\
$\mathbf{U O}_{\mathbf{3}} \cdot \mathbf{2 H}_{\mathbf{2}} \mathbf{O}^{(\mathrm{e})}$ & 6.0 & 5.2 & 376 & 39 \\
\hline
\end{tabular}

(a) non-homogenized batch experiment, (b)air-homogenised batch experiments, ${ }^{(c)}$ natural schoepite, ${ }^{(\mathrm{d})}$ reported by Giammar $2001^{39}$, and ${ }^{(\mathrm{e})}$ synthetic schoepite. 
Figure 1

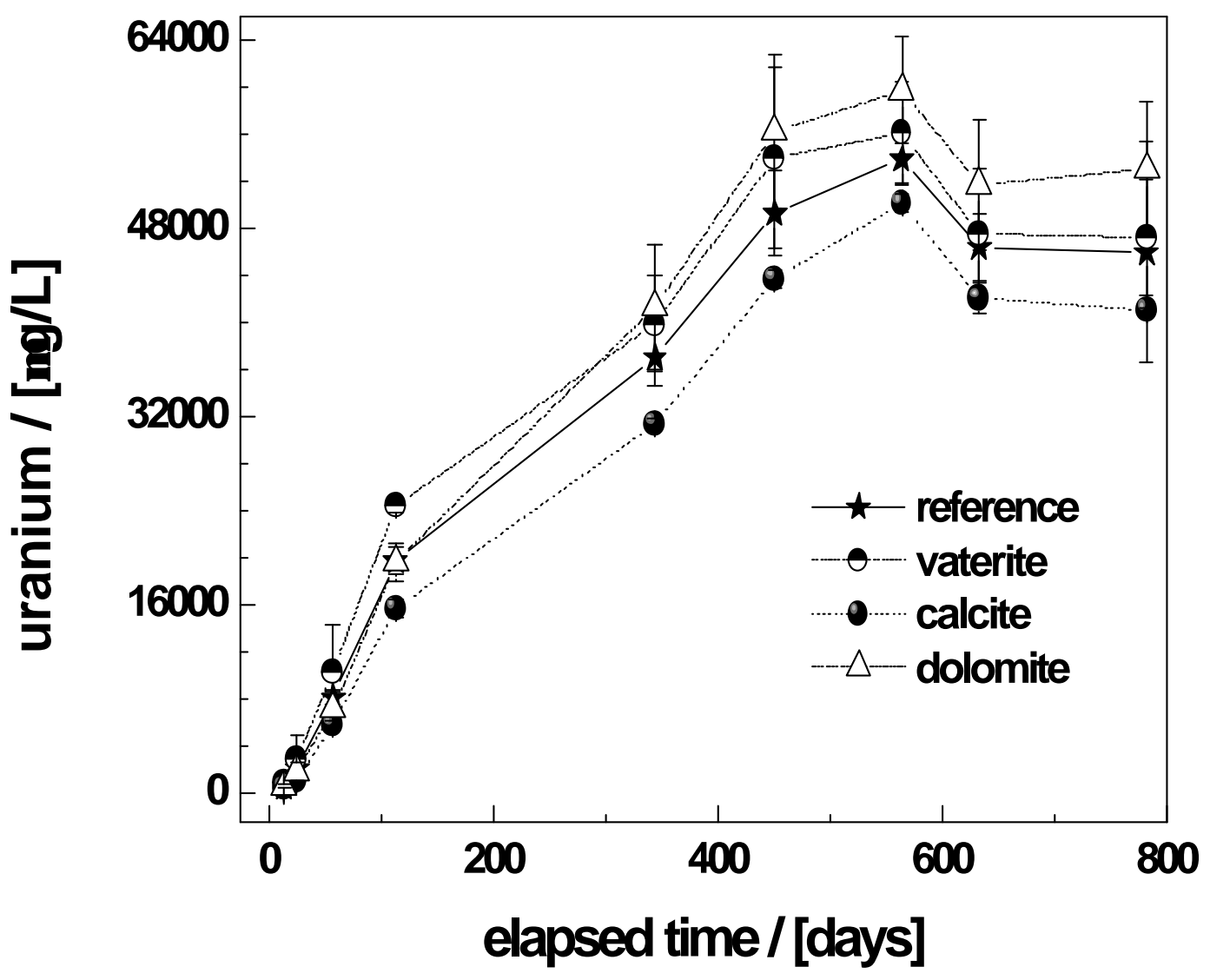


Figure 2

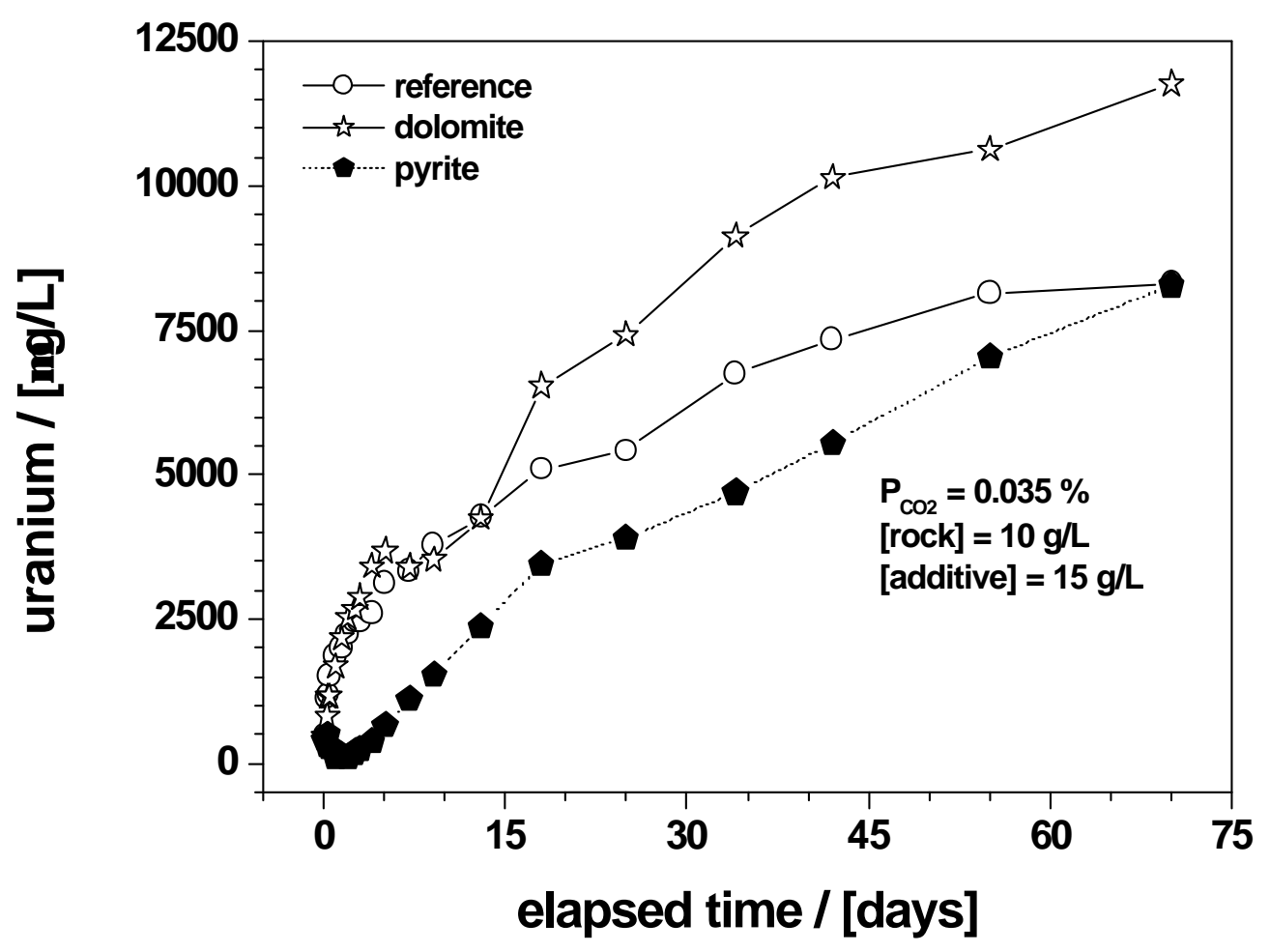


Figure 3
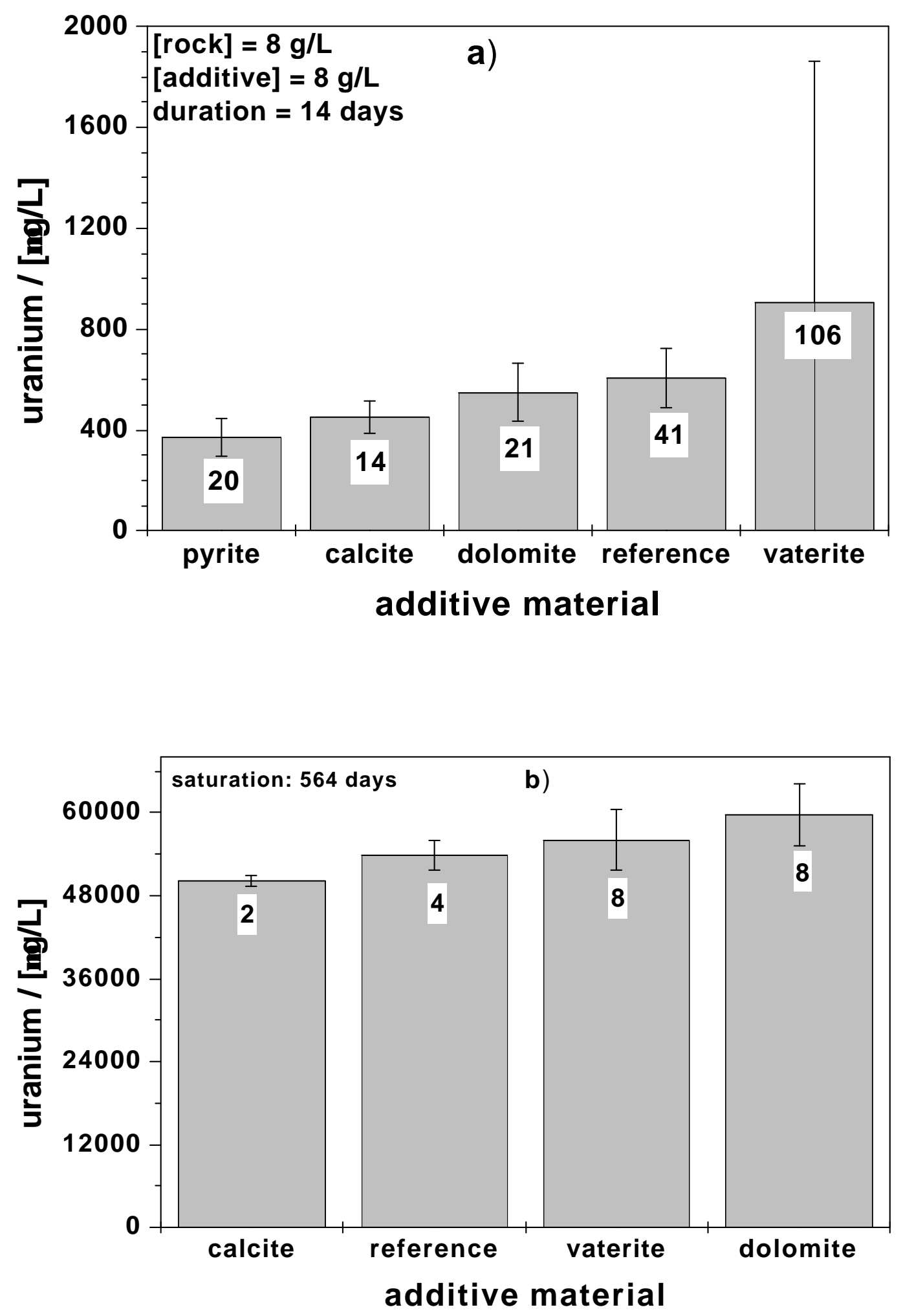


\section{Figure Captions}

Figure 1: Total U concentration for elution from powdered rock material (particle size of $0.250-0.315 \mathrm{~mm}$ ) in tap water as a function of additive material and time. The experiments were conducted in triplicate. Error bars provide absolute standard deviations.

Figure 2: Evolution of the total uranium concentration as a function of time in airhomogenized batch experiments. The experiment was conducted for 70 days. The lines are not fitting functions, they simply connect points to facilitate visualization.

Figure 3: Total uranium concentration in tap water as a function of additive material for 14 days (a) and 564 days (b) in closed system. The experiments were conducted in triplicate. Error bars give standard deviations. The values in the bars represent the relative errors (in \%). 